\title{
HUBUNGAN POLA ASUH ORANG TUA DAN KELUARGA DENGAN KEJADIAN DIARE PADA BALITA DI WILAYAH KERJA PUSKESMAS BIREM BAYEUN KECAMATAN BIREM BAYEUN KABUPATEN ACEH TIMUR TAHUN 2018
}

\author{
Relationship Of Parenting Parents And Families With Incidence Of Diarrhea At Toddlers In \\ The WorkingArea Of Birem Bayeun Public Health Center \\ Birem Bayeun District East Aceh Year 2018
}

\author{
Zuhrah $^{1}$,Agusdin $^{2}$, Mariamu $^{3}$
}

Program Studi Diploma III Akademi Kebidanan Harapan Ibu

\begin{abstract}
ABSTRAK
Diare merupakan kondisi dimana seseorang mengalami buang air besar lebih dari tiga kali sehari dengan konsistensi cair. Penyakit diare merupakan penyakit endemis di Indonesia dan juga merupakan penyakit potensial Kejadian Luar Biasa (KLB) yang sering disertai dengan kematian. Prevalensi tertinggi kasus diare terjadi pada kelompok umur balita. Hal ini disebabkan karena daya tahan tubuh balita yang masih lemah. Tujuan penelitian ini untuk mengetahui hubungan pola asuh orang tua dan keluarga dengan kejadian diare pada balita di Wilayah Kerja Puskesmas Birem Bayeun Kecamatan Birem Bayeun Kabupaten Aceh Timur tahun 2018.

Desain penelitian yang digunakan adalah analitik dengan rancangan cross sectional. Populasi dari penelitian ini adalah seluruh balita di wilayah kerja Puskesmas Birem Bayeun Kecamatan Birem Bayeun Kabupaten Aceh Timur tahun 2017 yang berjumlah 197 anak. Pengambilan sampel menggunakan rumus Slovin, didapatkan sebanyak 66 sampel. Penelitian dilaksanakan dari tanggal 21-27 Juni 2018 menggunakan kuesioner dengan cara wawancara. Uji statistik menggunakan uji chi-square.

Hasil penelitian menunjukkan bahwa dari 66 responden (100\%) terdapat 39 balita $(59,1 \%)$ yang tidak mengalami kejadian diare dan 27 balita $(40,9 \%)$ yang mengalami kejadian diare. Secara statistik ada hubungan pola asuh orang tua $(p$ value $=0,000)$ dan keluarga ( $p$ value $=0,000)$ dengan kejadian diare pada balita di Wilayah Kerja Puskesmas Birem Bayeun Kecamatan Birem Bayeun Kabupaten Aceh Timur tahun 2018.

Bagi masyarakat, khususnya ibu-ibu yang memiliki balira agar lebih menambah wawasan mengenai diare, terutama mengenai pencegahan diare.
\end{abstract}

Kata Kunci : Kejadian Diare, Pola Asuh Orang Tua, Keluarga

Daftar Pustaka : 27 (2011-2018) 
Journal of Healthcare Technology and Medicine Vol. 6 No. 2 Oktober 2020

Universitas Ubudiyah Indonesia

e-ISSN : 2615-109X

\begin{abstract}
Diarrhea refers to discharging feces more than three times a day with aqueous constitution. Diarrheal disease is an endemic disease in Indonesia and is also a potential illness of Extraordinary Occurrence (KLB) which is often accompanied by death. The highest prevalence of diarrheal cases occurs in the age group of children under five. This is because the immune system is still weak. The purpose of this study was to determine the relationship between parenting and family parenting with the incidence of diarrhea in infants at the Birem Bayeun District Health Center Birem Bayeun District, East Aceh district in 2018.

The research design used was analytical with cross sectional design. The population of this research is all children under five in the work area of Birem Bayeun Public Health Center, Birem Bayeun District, East Aceh Regency 2017 with total number of 197 children. Sampling using Slovin formula, obtained as many as 66 samples. The study was conducted from 21-27 June 2018 using questionnaires by interview. Statistical test using chi-square test.

The results showed that from 66 respondents (100\%) there were 39 children under five (59.1\%) who did not experience diarrhea and 27 toddlers (40.9\%) experienced diarrhea. Statistically there is relationship of parenting parenting ( $p$ value $=0,000$ ) and family ( $p$ value $=0,000)$ with diarrhea occurrence in balita at Working Area of Birem Bayeun Public Health Sub-District Birem Bayeun Regency of East Aceh 2018.

For the community, especially mothers who have balira to be more insightful about diarrhea, especially regarding the prevention of diarrhea.
\end{abstract}

Keyword : Incidence of Diarrhea, Parenting Parents, Families

References : :27(2011-2018) 
Journal of Healthcare Technology and Medicine Vol. 6 No. 2 Oktober 2020

Universitas Ubudiyah Indonesia

e-ISSN : 2615-109X

\section{PENDAHULUAN}

Penyakit diare masih merupakan masalah global dengan derajat kesakitan dan kematian yang tinggi di berbagai negara terutama di negara berkembang, dan sebagai salah satu penyebab utama tingginya angka kesakitan dan kematian anak di dunia (Kemenkes RI, 2012).

World Health Organization (WHO) menyebutkan bahwa diare merupakan penyakit kedua yang menyebabkan kematian pada anak-anak balita (bawah lima tahun). Anak-anak yang mengalami kekurangan gizi atau sistem imun yang kurang baik seperti pada orang dengan Human Immunodeficiency Virus (HIV) sangat rentan terserang penyakit diare. Diare sudah membunuh 760.000 anak setiap tahunnya. Sebagian besar orang diare yang meninggal dikarenakan terjadinya dehidrasi atau kehilangan cairan dalam jumlah yang besar (WHO, 2013).

Persentase diare ditemukan dan ditangani di Provinsi Aceh pada tahun 2016 sebesar 71,4\%. Angka penemuan kasus diare per 1.000 penduduk sebesar 270 atau sebanyak 137.599 kasus. Untuk wilayah Kabupaten Aceh Timur, jumlah kasus diare yang ditemukan sebanyak 11.105 kasus dan Kabupaten Aceh Timur menempati urutan keempat tertinggi penyumbang kasus diare di Provinsi Aceh dibawah Aceh Utara (16.024 kasus), Bireuen (11.978 kasus) dan Pidie (11.501 kasus) (Dinkes Aceh, 2017).

Bila dilihat per kelompok umur diare tersebar di semua kelompok umur dengan prevalensi tertinggi terdeteksi pada anak balita (1-4 tahun) yaitu 16,7\%. Sedangkan menurut jenis kelamin prevalensi laki-laki dan perempuan hampir sama, yaitu 8,9\% pada laki-laki dan 9,1\% pada perempuan. Prevalensi diare lebih banyak di perdesaan dibandingkan perkotaan, yaitu sebesar $10 \%$ di perdesaan dan $7,4 \%$ di perkotaan. Diare cenderung lebih tinggi pada kelompok pendidikan rendah dan bekerja sebagai petani/nelayan dan buruh. Berdasarkan penyakit menular, diare merupakan penyebab kematian peringkat ke-3 setelah TB dan Pneumonia (Kemenkes RI, 2012).

Berdasarkan Rekapitulasi Kasus Diare di Wilayah Kerja Puskesmas Birem Bayeun Kecamatan Birem Bayeun Kabupaten Aceh Timur (2018) dapat diketahui bahwa kejadian diare pada balita pada tahun 2017 adalah sebanyak 197 kasus. Secara klinis penyebab diare dapat dikelompokkan dalam 6 golongan besar yaitu infeksi (disebabkan oleh bakteri, virus atau infestasi parasit), malabsorpsi, alergi, keracunan, imunodefisiensi dan sebab-sebab lainnya. 
Journal of Healthcare Technology and Medicine Vol. 6 No. 2 Oktober 2020

Universitas Ubudiyah Indonesia

e-ISSN : 2615-109X

Penyebab yang sering ditemukan di lapangan ataupun secara klinis adalah diare yang disebabkan infeksi dan keracunan.

Menurut Kemenkes RI (2012), prevalensi tertinggi kasus diare terjadi pada kelompok umur balita. Hal ini disebabkan karena daya tahan tubuhnya yang masih lemah. Faktor risiko diare pada balita di Indonesia dibagi menjadi empat, yakni faktor lingkungan, faktor ibu, faktor anak dan faktor sosial ekonomi. Faktor lingkungan yang paling sering diteliti menjadi faktor risiko diare adalah jenis dan pencemaran sarana air bersih, serta kepemilikan jamban. Faktor ibu yang sering diteliti adalah perilaku ibu. Faktor anak yang sering diteliti adalah status gizi dan pemberian Air Susu Ibu (ASI) eksklusif. Faktor sosial ekonomi merupakan faktor risiko yang tidak terlalu signifikan sebagai faktor risiko diare.

Pola asuh dengan kejadian diare merupakan salah satu penyebab utama diare, yaitu tidak memberikan ASI secara penuh untuk 4-6 bulan pertama dari kehidupan, penggunaan jamban dan membuang tinja yang tidak sehat, menyimpan makanan masak pada suhu kamar (sanitasi makanan tidak baik), air minum yang tidak bersih atau tercemar dengan bakteri tinja, dan tidak mencuci tangan sesudah buang air besar, sesudah membuang tinja, atau sebelum menjamah makanan. Pola asuh orang tua kepada anaknya sangat memengaruhi kesehatan anaknya, pola asuh yang baik akan meningkatkan kesehatan anak dengan menghindari kejadian diare (Andreas, 2013).

Hasil survei awal yang peneliti lakukan di wilayah kerja Puskesmas Birem Bayeun, ditemukan $10 \mathrm{ibu}$ yang datang ke puskesmas untuk membawa anaknya berobat karena sakit diare. Dari hasil wawancara penulis dengan orang tua dan keluarga balita dapat diketahui bahwa kejadian diare yang menimpa balita dikarenakan kurangnya perhatian orang tua dalam memantau makanan yang dikonsumsi balita. Dalam hal ini, orang tua dan keluarga kurang memberikan batasan dan kendali terhadap balita. Balita belum mengetahui cara mencegah terjadinya penyakit, oleh karena itu orang tua dan keluarga harus berperan dalam mendidik anak, memberikan contoh, aturan dan batasan yang kesemuanya itu merupakan bagian dari pola asuh.

Diare adalah bertambahnya frekuensi defekasi lebih dari 3 kali per hari yang disertai dengan perubahan konsistensi tinja menjadi cair, kandungan air tinja lebih banyak dari biasanya lebih dari 200 gram atau 200 ml/24 jam (Andreas, 2013).

Menurut Kemenkes RI (2011), penyebab diare adalah:

1) Faktor Infeksi 
Journal of Healthcare Technology and Medicine Vol. 6 No. 2 Oktober 2020

Universitas Ubudiyah Indonesia

e-ISSN : 2615-109X

(1) Infeksi Enteral: Infeksi saluran pencernaan makanan yang merupakan penyebab diare pada anak.Infeksi interal meliputi:

(i) Infeksi Bakteri; Vibrio, E.Coli, salmonella, shigella Campylobacter, yersinia, Aeromonas dan sebagainya.

(ii) Infeksi Virus; Enterovirus Virus ECHO, Coxsackie, Poliomeyilitis, Adeno virus, Rotavirus, Astrovirus dan lain-lain.

(iii) Infeksi Parasit; Cacing (Ascaris, Trichuris, Oxyuris Strongyluides), Protozoa (Entamoeba Hystolitica, Giardia Clamblia, Trichomonas Hominis), Jamur (Candida Albicans).

(2) Infeksi Parenteral: Ialah infeksi diluar alat pencernaan seperti: Otitis Media Acut (OMA), Tonsilitis/Tonsilofaringitis, Bronco pneumonia, Enchefalithis dan sebagainya, keadaan ini terutama terdapat pada bayi dan pada anak berumur dibawah 2 tahun.

2) Faktor Malabsorbsi

(1) Malabsorbsi karbohidrat : Disakarida (Intoleransi laktosa, Maltosa dan Sukrosa); Monosakarida (Intoleransi glukosa, Fruktosa dan Galaktosa), Pada bayi dan anak yang terpenting dan tersering (Intoleransi Laktosa).

(2) Malabsorbsi Lemak.

(3) Malabsorbsi Protein.

3) Faktor Keracunan Makanan

Keracunan bahan kimia, keracunan oleh racun yang dikandung atau yang diproduksi Makanan basi, beracun, alergi terhadap makanan, ikan, sayur dan buah.

4) Faktor Penggunaan Antibiotik

Infeksi masih merupakan penyebab utama diare. Pada penelitian yang dilakukan oleh Indonesian Rotavirus Surveillenc Network (IRSN) dan Litbangkes pada pasien anak di 6 rumah sakit ,penyebab infeksi terutama disebabkan oleh Rotavirus dan Adenovirus (70\%) sedangkan infeksi karena bakhteri hanya 8.4\%.kerusakan villi usus karena infeksi virus (Rotavirus) mengakibatkan berkurangnya produksi enzim laktase sehingga menyebabkan malabsorbsi laktosa.

Menurut Kemenkes RI (2011), patofisiologi kejadian diare sebagai berikut:

1) Diare Sekretorik

Disebabkan oleh sekresi air dan elektrolit kedalam usus yang terjadi akibat gangguan absorbsi natrium oleh villus saluran cerna sedang kan sekresi klorida tetap berlangsung 
Journal of Healthcare Technology and Medicine Vol. 6 No. 2 Oktober 2020

Universitas Ubudiyah Indonesia

e-ISSN : 2615-109X

atau meningkat keadaan ini menyebabkan air dan elektrolit keluar dari tubuh sebagai tinja cair. Diare sekretorik ditemukan [pada diare yang disebabkan oleh infeksi bahteri akibat rangsangan pada mukosa usus oleh toksin ,misalnya toksi E.Coli atau V.Cholera.

2) Diare Osmotik

Mokosa usus halus adalah epitel berpori yang dapat dilalui oleh air dan elektrolit dengan cepat untuk mempertahankan tekanan osmotik antara lumen usus dan cairan ektrasel.oleh karena itu bila dilumen usus terdapat bahan yang secara osmotik aktif dan sulit diserap akan menyebabkan diare,Bila bahan tersebut adalah larutan isotonik air atau bahan yang larut maka akan melewati mukosa usus halus tanpa diarbsorbsi sehingga terjadi diare.

\section{METODE PENELITIAN}

Desain penelitian yang digunakan dalam penelitian ini adalah analitik dengan rancangan bedah lintang (cross sectional) yaitu suatu penelitian untuk mempelajari variabel dependen dan variabel independen secara bersamaan untuk mengetahui Hubungan Pola Asuh Orang Tua dan Keluarga dengan Kejadian Diare pada Balita di Wilayah Kerja Puskesmas Birem Bayeun Kecamatan Birem Bayeun Kabupaten Aceh Timur Tahun 2018.

Penelitian dilaksanakan di Wilayah Kerja Puskesmas Birem Bayeun Kecamatan Birem Bayeun Kabupaten Aceh Timur Tahun 2018. Populasi dalam penelitian ini adalah seluruh balita di wilayah kerja Puskesmas Birem Bayeun Kecamatan Birem Bayeun Kabupaten Aceh Timur tahun 2017 yang berjumlah 197 anak.

Pengambilan sampel dalam penelitian ini dilakukan dengan menggunakan teknik acak stratifikasi (stratified random sampling), yaitu mengambil perwakilan pada masing-masing desas. Pengambilan sampel perdesa dilakukan dengan cara menghitung jumlah populasi perdesa dibagi jumlah populasi keseluruhan dikali jumlah sampel yang dibutuhkan. Agar perimbangan sampel dari masing-masing strata itu memadai, maka dalam teknik ini sering pula dilakukan perimbangan antara jumlah anggota populasi berdasarkan masing-masing strata.

Oleh sebab itu maka disebut pengambilan sampel secara proporsional stratified sampling. Pelaksanaan pengambilan sampel dengan stratified, mula-mula kita menetapkan unit-unit anggota populasi dalam bentuk strata yang didasarkan pada karakteristik umum dari anggota-anggota populasi yang berbeda-beda. Setiap unit yang mempunyai karakteristik umum 
Journal of Healthcare Technology and Medicine Vol. 6 No. 2 Oktober 2020

Universitas Ubudiyah Indonesia

e-ISSN : 2615-109X

yang sama, dikelompokkan pada satu strata, kemudian dari masing-masing strata diambil sampel yang mewakilinya..

Data yang telah di peroleh dari hasil angket (kuesioner) diolah secara komputerisasi. Pengolahan data melalui langkah berikut :

1) Collecting

Mengumpulkan data yang berasal dari kuesioner, angket maupun observasi.

2) Checking

Dilakukan dengan memeriksa kelengkapan jawaban kuesioner atau lembar observasi dengan tujuan agar data diolah secara benar sehingga pengolahan data memberikan hasil yang valid dan realiabel dan terhindar dari bias

3) Coding

Pada langkah ini peneliti melakukan pemberian kode pada variabel-variabel yang diteliti.

4) Entering

Data entry, yakni jawaban-jawaban dari masing-masing responden yang masih dalam bentuk "kode" (angka atau huruf) dimasukkan ke dalam program komputer yang digunakan peneliti yaitu program SPSS for Windows.

5) Data Processing

Semua data yang telah di input ke dalam aplikasi komputer akan diolah sesuai dengan

kebutuhan dari penelitian (Muhammad, 2013).

Setelah dilakukan pengumpulan data kemudian data dianalisa menggunakan statistik deskriptif untuk mendapatkan dalam bentuk tabulasi, dengan cara memasukkan seluruh data kemudian diolah secara statistik deskriptif yang digunakan untuk melaporkan hasil dalam bentuk distribusi frekuensi dan presentase (\%) dari masing-masing variabel. Setelah diketahui karakteristik masing-masing variabel pada penelitian ini maka analisis dilanjutkan pada tingkat bivariat. Untuk mengetahui hubungan (korelasi) antara variabel bebas (independent variable) dengan variabel terikat (dependent variable). Untuk membuktikan adanya hubungan yang signifikan antara variabel bebas dengan variabel terikat digunakan analisis Chi-square, pada batas kemaknaan perhitungan statistik $p$ value $(0,1)$. Apabila hasil perhitungan menunjukkan nilai $\mathrm{p}<p$ value $(0,1$.$) maka dikatakan \left(\mathrm{H}_{0}\right)$ ditolak, artinya kedua variabel secara statistik mempunyai hubungan yang signifikan. Kemudian untuk menjelaskan adanya asosiasi 
Journal of Healthcare Technology and Medicine Vol. 6 No. 2 Oktober 2020

Universitas Ubudiyah Indonesia

e-ISSN : 2615-109X

(hubungan) antara variabel terikat dengan variabel bebas digunakan analisis tabulasi silang (Muhammad, 2013).

Aturan yang berlaku pada uji Chi Square adalah sebagai berikut:

1) Bila pada tabel $2 \times 2$ dijumpai nilai harapan (expected value $=\mathrm{E}$ ) kurang dari 5, maka uji yang digunakan adalah Fisher Exact.

2) Bila pada tabel 2 x 2 dan semua nilai $\mathrm{E}>5$ (tidak ada nilai $\mathrm{E}<5$ ), maka nilai yang dipakai sebaiknya Continuity Correction.

3) Bila tabelnya lebih dari $2 \times 2$, misalnya $3 \times 2,3 \times 3$ dan lain-lain, maka digunakan uji Pearson Chi Square (Muhammad, 2014).

\section{HASIL PENELITIAN}

1) Analisis univariat menunjukkan Dari 66 responden (100\%) terdapat 39 balita $(59,1 \%)$ yang tidak mengalami kejadian diare dan 27 balita (40,9\%) mengalami kejadian diare.

2) Hasil analisis bivariat menunjukkan Ada hubungan pola asuh orang tua dengan kejadian diare pada balita di Wilayah Kerja Puskesmas Birem Bayeun Kecamatan Birem Bayeun Kabupaten Aceh Timur tahun 2018 dengan $p$ value $0,000(\mathrm{P}<0,1)$.

3) Ada hubungan keluarga dengan kejadian diare pada balita di Wilayah Kerja Puskesmas Birem Bayeun Kecamatan Birem Bayeun Kabupaten Aceh Timur tahun 2018 dengan p value $0,000(\mathrm{P}<0,1)$.

\section{PEMBAHASAN}

Menurut Kemenkes RI (2012), prevalensi tertinggi kasus diare terjadi pada kelompok umur balita. Prevalensi diare lebih banyak di perdesaan dibandingkan perkotaan. Diare cenderung lebih tinggi pada kelompok pendidikan rendah dan bekerja sebagai petani/nelayan dan buruh. Secara klinis penyebab diare dapat dikelompokkan dalam 6 golongan besar yaitu infeksi (disebabkan oleh bakteri, virus atau infestasi parasit), malabsorpsi, alergi, keracunan, imunodefisiensi dan sebab-sebab lainnya. Faktor risiko diare pada balita di Indonesia dibagi menjadi empat, yakni faktor lingkungan, faktor ibu, faktor anak dan faktor sosial ekonomi. Faktor ibu yang sering diteliti adalah perilaku ibu. Perilaku ibu merupakan faktor risiko yang signifikan sebagai faktor risiko diare.

Sejalan dengan pendapat Notoatmodjo (2012) yang menyebutkan perilaku sebagai salah satu faktor yang memengaruhi kesehatan mempunyai andil besar dalam memengaruhi status kesehatan karena perilaku dapat mengendalikan faktor lain, yakni lingkungan dan 
Journal of Healthcare Technology and Medicine Vol. 6 No. 2 Oktober 2020

Universitas Ubudiyah Indonesia

e-ISSN : 2615-109X

pelayanan kesehatan. Terciptanya lingkungan sehat tidak terlepas dari kontribusi perilaku manusia. Pelayanan kesehatan juga tidak akan berhasil bila tidak ada perubahan perilaku meskipun sarana kesehatan telah memadai.

Menurut asumsi peneliti, lebih banyaknya balita yang tidak mengalami kejadian diare dari pada balita yang mengalami kejadian diare di Wilayah Kerja Puskesmas Birem Bayeun Kecamatan Birem Bayeun Kabupaten Aceh Timur Tahun 2018 dikarenakan ibu sudah mulai memiliki perilaku yang baik terhadap kejadian diare, seperti menerapkan Perilaku Hidup Bersih dan Sehat sehingga kejadian diare pada balita cenderung terhindari atau dapat dicegah, namun masih adanya balita yang mengalami kejadian diare di Wilayah Kerja Puskesmas Birem Bayeun Kecamatan Birem Bayeun Kabupaten Aceh Timur Tahun 2018 menunjukkan perlunya upaya dari pihak-pihak terkait untuk merubah perilaku ibu dari yang sebelumnya berperilaku kurang baik menjadi berperilaku baik.

Berdasarkan hasil analisis bivariat dapat diketahui bahwa balita dengan pola asuh orang tua yang otoriter mayoritas tidak mengalami kejadian diare, balita dengan pola asuh orang tua yang demokratis mayoritas tidak mengalami kejadian diare dan balita dengan pola asuh orang tua yang permisif mayoritas mengalami kejadian diare. Hal ini menunjukkan bahwa balita dengan orang tua yang menerapkan pola asuh permisif cenderung mengalami kejadian diare. Hasil uji statistik menunjukkan bahwa ada hubungan pola asuh orang tua dengan kejadian diare pada balita di Wilayah Kerja Puskesmas Birem Bayeun Kecamatan Birem Bayeun Kabupaten Aceh Timur tahun 2018.

Hasil penelitian ini sejalan dengan hasil penelitian yang dilakukan oleh Ayu Rosyidah (2013) yang menunjukkan bahwa ada hubungan antara tipe pola asuh orang tua dengan kejadian diare pada balita. Hasil penelitian ini juga sejalan dengan hasil penelitian yang dilakukan oleh Andreas (2013) yang menunjukkan bahwa ada hubungan yang signifikan antara perilaku ibu dalam mengasuh balita dengan kejadian diare.

Menurut asumsi peneliti, adanya hubungan pola asuh orang tua dengan kejadian diare pada balita di Wilayah Kerja Puskesmas Birem Bayeun Kecamatan Birem Bayeun Kabupaten Aceh Timur tahun 2018 dikarenakan perilaku kesehatan (yang berhubungan dengan diare) merupakan aspek yang penting dalam pengasuhan orang tua kepada anak. Pola asuh orang tua memengaruhi ada atau tidak adanya diare pada balita. Pembentukan pola asuh anak yang baik dimulai dari komunikasi yang efektif antara orang tua dan anak. Oleh karena itu, sebaiknya ajak anak berkomunikasi setiap anak menginginkan sesuatu, karena komunikasi orang tua dengan anak memiliki manfaat yang besar terhadap perkembangan anak. 
Journal of Healthcare Technology and Medicine Vol. 6 No. 2 Oktober 2020

Universitas Ubudiyah Indonesia

e-ISSN : 2615-109X

\section{DAFTAR PUSTAKA}

Kemenkes RI. (2011), Pedoman Pengendalian Penyakit Diare. Jakarta: Direktorat Jenderal Pengendalian penyakit dan penyehatan Lingkungan.

Kemenkes RI. (2012). Lintas Diare (lima langkah tuntaskan diare). Jakarta: Direktorat Jenderal Pengendalian penyakit dan Penyehatan Lingkungan Kementerian Kesehatan Republik Indonesia.

WHO. (2013). Diarrhoeal Disease. Diambil dari https:// www.who.int/mediacentre/factsheets/fs330/en/. Diakses oleh: Zuhrah. 1 April 2018. 08.30 wib.

Dinkes Aceh. (2017). Profil Kesehatan Provinsi Aceh Tahun 2016. Banda Aceh: Dinas Kesehatan Provinsi Aceh.

Puskesmas Birem Bayeun. (2018). Rekapitulasi Kasus Diare di Wilayah Kerja Puskesmas Birem Bayeun Kecamatan Birem Bayeun Kabupaten Aceh Timur Tahun 2017.

Andreas. (2013). Perilaku Ibu Dalam Mengasuh Balita Dengan Kejadian Diare. Jurnal Keperawatan, Volume IX, No. 2, Oktober 2013 ISSN 1907 - 0357.

Muhammad, Iman. (2013). Panduan Penyusunan Karya Tulis Ilmiah Bidang Kesehatan. Bandung: Citapustaka Media Perintis.

Muhammad, Iman. (2014). Pemanfaatan SPSS Dalam Penelitian Bidang Kesehatan. Bandung: Citapustaka Media Perintis.

Notoatmodjo, Soekidjo. (2012). Promosi Kesehatan Dan Perilaku Kesehatan. Jakarta: Rineka Cipta.

Rosidah, Ayu. (2013). Hubungan antara Pola Asuh Balita dan Kejadian Diare (Studi Eksplanatif Tindakan Pola Asuh Orangtua di Kawasan Endemik Diare di Kelurahan Pakis, Kecamatan Sawahan, kota Surabaya). Jurnal Departemen Sosiologi, FISIP, Universitas Airlangga. 